\title{
JAPAN AND MODERN ARCHITECTURE, 1945-1970. DISCOURSE IN THE MID-20TH-CENTURY EUROPE. 1960S: EMANCIPATION, CRITICISM
}

\author{
ONDŘEJ HOJDA \\ Ústav dějin umění AV ČR; Technická univerzita v Liberci \\ on.hojda@gmail.com
}

\begin{abstract}
This text is based on a section from the author's dissertation titled Japan and Modern Architecture, 1945-1970. Discourse in the mid-20th-century Europe, examining the ideas about Japanese architecture in Western, mainly European discourse between 1945 and 1970. The dissertation maps the discourse on Japan from a comparative perspective. Building on sources from different countries, it identifies the main topics that were associated with Japan in the architectural context and shows their broader significance in the global architectural debate. It deals with the image of another culture: the focus is on both the history of ideas and visual representations, mainly photography. The sources are mostly printed media: architectural magazines and books on architecture in Western languages: English, German, French, Italian, Norwegian and Czech.

What follows are excerpts from chapter II.6. of the original dissertation thesis. They introduce the change in perception of Japan that followed after 1960, and a case study of the writings on Japan by Bernard Rudofsky.
\end{abstract}

Keywords: 20th Century architecture - architecture after World War II - Japanese architecture - Europe-Japan relationships in art and architecture - Bernard Rudofsky

\section{"Japan cannot be fathomed as matter-of-factly as England, Holland, or Disneyland."}

Bernard Rudofsky, $1965^{1}$

\section{Introduction}

The 1960s brought profound changes in the perception of Japan². While looking the pages of international architecture magazines, the biggest change we can observe from around the year 1960 is the sheer rise of presence of presence of Japan in the architectural media: many more projects were presented than before, and the range of subjects connected to Japan expanded radically. In the previous years, the works of modern

1 Bernard Rudofsky, Kimono Mind. An Informal Guide to Japan and the Japanese, New York 1965), p. 9.

2 The author's dissertation, documented in the previous chapters patterns formed in thinking about Japan in the West, and how the Japanese architects shaped the debate about their own tradition and its image abroad. 
western-trained masters (Maekawa, Sakakura, and a few other favourites) occasionally occurred in books and magazines, they now gradually gave way to an extensive coverage of the projects of Kenzo Tange, and the Metabolist generation. Two outstanding events, the Tokyo Olympics 1964 and the Osaka Expo in 1970 were presented by means of their architecture, and they gave further material for discussion and filled Western magazines with Japanese-bound content. The discourse on Japanese architecture diversified, and offered a more varied set of images: they sometimes went past each other, sometimes brushed against each other, sometimes collided. From this viewpoint, three trends stand out in the 1960s: The emancipation of Japanese contemporary architecture on the global scene allowed for new perspectives, a growing interest interest in the urban realm, and a focus on the governing principles behind architectural and urban phenomena.

The newly acquired international status of contemporary Japanese architecture also meant, however, that it could be subject to criticism, losing the protective shield of exoticism. It could get quite harsh. The most negative impressions were often to be heard about the Japanese urban space. While Western authors in the previous decade either ignored the newly growing urban landscape in Japan, or briefly mentioned it as ugly, during the 1960s we see more and more comments on the apparent chaos of the Japanese cityscape, causing disorientation, sensory oversaturation, and even fear. Since Japan was seen as a place future is already happening, some visitors embraced it, others, for the same reason, saw it as a threat. Authors such as Günther Nitschke - in his extraordinarily long articles - and others such as Peter Güller connected this interest in general principles with urbanism and landscape, trying to reveal even deeper formative forces. Bernard Rudofsky, while cultivating a non-conformist attitude, was well aware of the context of his time when writing about Japan. First of his articles appeared in the Italian Domus already after, his first Japanese sojourn in 1956, and then largely expanded in his 1965 book, The Kimono Mind.

\section{Apprehending the urban realm}

Writing on the Japanese city was becoming much more common. The Swiss magazine Werk, for instance, dedicated one issue to the "Image of the City" (Stadtbild), then a hotly debated topic thanks to the newly published book by Kevin Lynch of the same name. In this context, an introduction to Fumihiko Maki's "Group Form,"3 appeared. Japanese architecture was on the front cover of Architectural Design after just half a year, in May 1965: this time, it was Tange's Yoyogi Olympic Halls. ${ }^{4}$ This time it was not just the spectacular features of the giant tent structures which garnered attention, but the entire urban megalopolis of Tokyo. "In Tokyo, there is less than one square yard of open space perperson, and it continues to fall as the population builds up at the rate of 300000 a year in Tokyo alone. One must actually consider the whole conurbation of Tokyo - KawasakiYokohama, whose total population is some twenty million, in thinking of urban problems

3 Fumihiko Maki, 'Group Form,' Werk 7, 1963, pp. 258-263.

4 Architectural Design, May 1965. 
of these cities." Jeremy Dodd tackled the issue of the staggering urbanization in Japan a broader manner: "The virtual destruction of the Japanese industry made a new start inevitable, the process of reconstruction from scratch has given the country a chance to re-organize and re-equip." " Little city planning, however, have actually been carried out: "Tokyo and Osaka (...) have risen from the delicate piles of wood-ash to become fantastic, sprawling jungles of buildings of all shapes and sizes, built on tiny plots (...)."7 Canals, which used to provide some open space as well as definition to the various 'quarters' were now gradually converted into expressways, parks were filled with buildings "with the justification that the buildings are for public purposes." The city's streets and alleys were until now "just right for the pedestrian, bicycle or even scooter; but in the ordinary streets there is no pavement and the citizens are increasingly pushed around by vehicles the poles supporting the dense overhead wirescape often provide the only safe refuge! (...) Public transportation above the ground packed to capacity ... a monorail has been constructed - the world's longest." In building, "each individual building owner follows his fancy, which results in a varying degree of chaos these days." In short, the experience of the Japanese city was distressing and chaotic.

With the elevated expressways, a new spatial experience entered Japan, inducing to the visitors a sense of emptiness, disconnected from the lively Japanese street. A few years later Andrei Tarkovsky used a long shot taken from a slightly dizzying car drive on a Tokyo expressway to evoke a profoundly dystopian atmosphere in his film Solaris (Солярис, 1972).

The rather confusing and stressful impression from the public areas - probably similar to the one from other Asian countries - quickly retreats when speaking about interiors. Dodd returns to the calming role of tradition, and stresses its role for the contemporary: "The interior of the Japanese house, with its flexible spatial character is already well known. But in any study of Japanese modern architecture it is well to remember its deep underlying influence. The quality of light available through the translucent shoji, or soft rice paper reflected from natural materials like the wooden framework, corridor floor and ceilings, the heavy paper of the fusuma or sliding doors used between rooms, and the tatami, or woven rice straw mat units, is something known to all Japanese. Foreign styles and fashions have some influence on the public, but there is still a strong preference for natural materials."

Well aware of the planning initiatives from contemporary Japanese architects, Dodd rather curiously - saw the perspective for Japanese architecture as a continuation of the development in Europe: "Japanese architecture seems to be forward looking and vigorous. At its best it is continuing of modern architecture in Western Europe and develop it further. Many mistakes are made, and clichés from other lands are incorporated that must be expected with the rapid growth of architecture in this country."

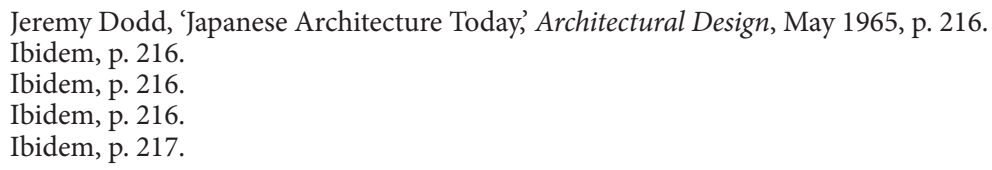




\section{Bernard Rudofsky in Domus (1956-1957), and The Kimono Mind (1965)}

When Bernard Rudofsky began introducing Japan in the Italian magazine Domus in the first of his articles in $1956^{10}$, he was not an unknown author in this magazine: when he resided in Italy in the 1930s, he occasionally contributed to the magazine. Austrian by origin, Bernard Rudofsky (1905-1988), born in Zauchtel in Moravia (today Suchdol nad Odrou, Czech Republic) adopted several homes including Italy and Brazil before emigrating to the United States in 1941, and travelled extensively his entire life. Japan played a special role for him. He travelled there in 1955 and then again in 1958-1960, staying for a year and a half. The first stay resulted in a series of articles for Domus, published in three issues in 1956 and 1957. These texts were included and extended, together with several others, in a book called The Kimono Mind ${ }^{11}$ (1965).

Rudofsky's position both within and without the Modern movement is already a subject of an interesting debate. ${ }^{12}$ Rudofsky was able to simultaneously ironize modern architecture and work with its leading institution, the New York Museum of Modern Art, from the 1940s onwards. The best known among them remains the Architecture Without Architects (1964) which toured the world for years ${ }^{13}$. He also befriended leading modernist architects: Walter Gropius endorsed Rudofsky's Fulbright application which enabled him a second stay of eighteen months as a visiting professor in Japan in 1958-1960. Rudofsky's goals were, however, substantially different from his architect colleagues.

During his second extensive stay in Japan between 1958 and 1960, Rudofsky gathered Japanese vernacular graphics, which formed a basis of an exhibition he prepared for MoMA in $1961^{14}$. It consisted of "maps, illustrated books and other graphic material executed by anonymous craftsmen over the past 250 years." 15 This collection was then also the source of illustrations for The Kimono Mind. Besides, Rudofsky prepared several lectures that remained unpublished, and his biography lists also a non-realized exhibition about Japan from $1972^{16}$.

In The Kimono Mind, readers were presented with a combination of travelogue and cultural criticism in a series of witty essays determined to go beyond the usual ways. The scope of topics that Rudofsky writes about is extremely broad, but still differs almost in every way from the architectural mainstream of his time. His approach is roughly speaking anthropological, with a preference for observation of everyday life, habits, and rituals

10 Bernard Rudofsky, 'Introduzione al Giappone (I)', Domus 319, 1956, pp. 45-49. The three articles published in 1956-1957 in Domus in an Italian translation, plus a fourth one, previously unpublished, are available in the English original in Andrea Bocco Guarneri: Bernard Rudofsky: A Humane Designer, Wien/NewYork 2003, pp. 209-226.

11 Rudofsky, Kimono Mind. An Informal Guide to Japan and the Japanese, New York 1965.

12 See Guarneri (note 9); Felicity Scott, 'Underneath Aesthetics and Utility. The Untransposable Fetish of Bernard Rudofsky,' Assemblage, 38, 1999, pp. 58-89; Architekturzentrum Wien (ed.), Lessons from Bernard Rudofsky. Life as a Voyage, Basel 2007.

13 Bernard Rudofsky, Architecture Without Architects. A Short Introduction to Non-Pedigreed Architecture, New York 1964.

14 The exhibition took place June 3 - July 13, 1961. See https://www.moma.org/calendar/exhibitions 13413.

15 MoMA Press release, June 3, 1961, available at https://www.moma.org/documents/moma_press-release 326237.pdf, retrieved 31. 7. 2017.

16 Guarneri (note 9). 
instead of describing forms, and shows a penchant for peculiarities. The themes range from his long-term interest in clothing and shoeware, as already the book's title signals (The Kimono Mind), over hot baths (Hedonism of the Destitute), gender roles (Ladies Last), to eating habits, and train travel. Among all these, Rudofsky does dedicate one chapter to the Japanese house (A House for the Summer ${ }^{17}$ ), and another one to the urban realm. This last essay, Forbidden Directions, belongs to his most interesting ones.

Even orthodox Modernists - including Bruno Taut, Charlotte Perriand and Walter Gropius - were impressed by Japan's historical tradition. Rudofsky embraced the past with an unusual affection and profound study. Although he did not understand Japanese, he read all kinds of Western sources about Japan down to the first notes of the Jesuit missionaries. He was thus more prone to critically grasp the conditions of learning about a different culture, and to distance himself from the actual intellectual fashions. A recurrent theme of his is thus the history of Western (mis-)understandings of Japan including long, humorous digressions. A constant interest of Rudofsky, we can say, is to subvert the established ways of representing Japanese culture.

This does not mean he would always be correct, or that he would abstain from subjective comments. Quite the opposite: Rudofsky is often very personal and opinionated. A source of amusement in his writing, after all, is his own confusion and clumsiness as a Westerner encountering Japanese reality. Yet these difficulties are ultimately turned into a more profound reflection on understanding cultural codes. Rudofsky did not pretend that the exploration of a distant culture goes always smoothly: "Although maps have long been declassified as top secret, the country is by no means an open book. The foreigner who tries to escape the routine of orthodox sight-seeing finds himself immobilized by unexpected obstacles. Mountains become inaccessible, roads impassable, waters dangerous, inns unaccommodating. Japan shuts up like an oyster." 18

Recently, Felicity D. Scott looked at Rudofsky's opinions about visual communication and orientation, presenting his Japanese experience as central ${ }^{19}$. Her research also revealed that Rudofsky's contending with Japanese culture had facets that were less jocular than his published writings may suggest. After his first stay in Japan in 1955, he expressed an intention of studying Westernization of Japan and the Japanese house and city as a "rear-view mirror" of the lifestyle in the United states, but this "strategy failed in face of what he encountered: a more complex and less discernible (at least to him) assemblage of sociocultural and economic forces at work," as Scott comments. ${ }^{20}$

One quality Rudofsky observed in Japan is approaching problems in an oblique, indirect manner. Rudofsky's own writing is often ambiguous in its message, both confirming and challenging the "us and them" attitude of a Western mind toward the other. Ruth Benedict's Chrysanthemum and the Sword is another obvious inspiration ${ }^{21}$, as can be seen when he writes about the changing clothing habits in Japan:

"When felt hats, leather boots, and tubular dress were decreed by law, and an imperial edict informed the nation that European clothes were concomitants of a more civilized life,

17 Rudofsky (note 10), p. 112-131.

18 Rudofsky (note 10), p. 85.

19 Felicity Scott, Disorientation: Bernard Rudofsky in the Empire of Signs, Berlin 2016.

20 Scott (note 18), referring to Rudofsky's letter to Serge Chermayeff, November 13, 1960.

21 Benedict, Chrysanthemum and the Sword, Boston 1946. 
the Japanese found a compromise in retaining the native costume for intramural use and as holiday dress. Their genius for avoiding clear-cut solutions enables them to assimilate things foreign without budging in their own way. Not for them the anguish of having to make a choice, not for them the scruples of a convert. (...) As so often in their history the Japanese were able to have their cake and eat it too."22

A Japanese reviewer of Rudofsky's book speaks rather sympathetically about "small inaccuracies, half-truths and overstatements", these however "rather enhance the atmosphere of a gallant adventurer's exploring new land." 23

In order to challenge the increasing role of visuality, Rudofsky deliberately renounced photography as illustration to his book. That meant keeping aside the excellent photos of his own making, with the only exception of the dust cover dust cover of The Kimono Mind. "In a period when all travel books were having recourse to the appeal of photographic image," 24 Rudofsky relies fully on old woodcuts and drawings for illustration. With his Japanese experience Rudofsky concluded that any images are inadequate, and the one he picks are "primarily meant to convey some of the aroma of the Japanese cultural climate," since "Japan cannot be fathomed as matter-of-factly as England, Holland, or Disneyland." 5 This said, Rudofsky's choice of illustrations is extraordinary, drawing almost uniquely from his personal collection of black-and white woodcut prints, adding also a contemporary restaurant menu full of ridiculous mistranslations.

Writing about buildings, Rudofsky never thought of them outside of the rich fabric of culture. Like Bruno Taut, Rudofsky maintains that "the most interesting feature of the house is not its material appearance but its life." ${ }^{26}$

"The Japanese house has defied dispassionate analysis. From the lukewarm notices of the earliest Western chroniclers - the Jesuit missionaries and Dutch merchants in the sixteenth and seventeenth centuries - to the panegyrics of contemporary travelers, it represents a stout paradox. Taken by many to be the most elegant shelter ever design for a man, it also marks the furthest departure from common sense." 27

Rudofsky quickly recognized that the modernists had seen the Japanese house in a heavily abstracted way, yet he still deemed this misappropriation as "not only perfectly valid but invaluable," as he wrote to Walter Gropius in a private letter. He also explained that Japan developed "standardization, prefabrication, and mobility (...) as possibilities centuries before." ${ }^{28}$ Finally, he saw the qualities of the traditional Japanese house as distinctive and not so dissimilar from the other modernists after all: "The Japanese housemore precisely, the traditional Japanese house, a venerable institution which has been the object of much admiration and occasionally of scorn - is but one of the houses that have proved immune to the fashions of the day." 29

"Nothing too much is in it. Protest against ostentation. Serenity, introspection. Modesty, formality, nobility, and reserve. It is opposed to everything that is garish, and loud. (...) [It

22 Rudofsky (note 10), p. 59.

23 Makoto Ueda, Review of Kimono Mind, Pacific Affairs, 41(2) (1968), p. 286.

${ }^{24}$ Guarneri (note 9), p. 57.

${ }^{25}$ Rudofsky (note 10), p. 9.

26 Bruno Taut, Houses and People of Japan, Tokyo, 1937, p. 191.

27 Rudofsky (note 10), p.116-118.

28 Scott (note 18), p. 64, referring to an unpublished letter of Rudofsky to Gropius, 23 November 1959.

29 Rudofsky (note 10), p. 113. 
is] the oriental house at its best... it is all house, all shelter, a true sanctuary for man."30 Yet still, his description of these values is highly original: "It is a house turned outside in, except that there never was much of an outside. There are no windows to look out from or into and subsequently no window curtains. No carpets or rugs eclipse the floor; no chairs, no beds encroach on its void. Apart from the annual replacement of the floor mats, the house in near-immutable. Long regarded as the conceit of practical jokers, of late the Japanese house has been looked upon as a triumph of ingenuity, indeed, a work of art." 31

The significance of Rudofsky's work for the understanding of Japan may sometimes hide beneath his satirical tone. His reading of cultural codes, however, is highly original, subversive, and ahead of his time: In the age when transparence and openness were constantly promoted as prime values of modern architecture, Rudofsky praised the obscurity of the Japanese house and the indirectness of wayfinding in it. The novelty approach may be best seen in his approach to the urban space: In the age when his modernist colleagues called for restrictions on street signs to avoid chaos and bad typography, Rudofsky relished on the overload of incomprehensible Japanese advertising lights glowing in the cities at night ${ }^{32}$. In the times when the emerging Japanese cityscape appeared threatening and downright ugly even to architects who loved the Japanese houses, Rudofsky suggested to expand the interest in Japanese architecture onto the urban realm.

\section{SUMMARY}

\section{Japan and Modern Architecture, 1945-1970. Discourse in the mid-20th-century Europe. 1960s: Emancipation, Criticism}

This text is based on a section (namely the chapter (II.6.) of the author's dissertation titled Japan and Modern Architecture, 1945-1970. Discourse in the mid-20th-century Europe. It examines the ideas about Japanese architecture in Western, mainly European discourse between 1945 and 1970. In the 1920s, architects began to notice surprising similarities between the principles of modern architecture and traditional Japanese building: like typical modernist buildings, traditional Japanese houses stand on vertical supports, have a free floor plan and sliding walls, open to the exterior and seem to be based on very similar aesthetics with a minimum of furniture. Gradually, Japan came to be seen as an indirect forerunner of architectural modernism, and especially after World War II, a massive wave of interest formed, manifest in the architectural press and in separate publications. Architectural history has not, however, paid enough attention to this phenomenon so far. The dissertation maps the discourse on Japan on the basis of a comparative perspective. Building on sources from different countries, it identifies the main topics that were associated with Japan in the architectural context and shows their broader significance in the global architectural debate. It deals with the image of another culture: the focus is on both the history of ideas and visual representations, mainly photography. The

30 Bernard Rudofsky, unpublished lecture about Japan, with slides, 1960. Quoted in: Guarneri (note 9), p. 44.

31 Rudofsky (note 10), p. 113.

32 This is the well expounded of the first half of Felicity Scott's book, see Scott (note 18), p. 11-56. 
sources are mostly printed media: architectural magazines and books on architecture in Western languages: English, German, French, Italian, Norwegian and Czech.

A major part of the dissertation analyzes the ways in which Japanese culture was interpreted in the above mentioned sources, especially in texts written by the architects. It first stops in more detail with two writing architects from the 1930s, Tetsurō Yoshida and Bruno Taut, followed by writings on Japan from the post-war period by e.g. Walter Gropius. The wave of interest in traditional Japanese construction seems to have culminated in the second half of the 1950s. Around 1960 the attention turned to the present, with the help of the increasingly vocal Japanese architects. The third part of the dissertation then interprets these sources from a different perspective. The focus is on key terms frequented in Western debates about Japanese architecture and culture, such as "flexibility," "standardization," or "nature,"; these terms are the subject of deeper criticism and are related to contemporary debates in Europe. At the end, the dissertation includes a separate study devoted to the complex concept of space.

\section{SELECTED BIBLIOGRAPHY}

Architectural Design, May 1965.

Architekturzentrum Wien, Monika Platzer (eds.), Lessons from Bernard Rudofsky. Life as a Voyage, Basel 2007.

Ruth Benedict, Chrysanthemum and the Sword, Boston 1946.

Jeremy Dodd, 'Japanese Architecture Today', Architectural Design, May 1965, p. 216.

Andrea Bocco Guarneri, Bernard Rudofsky: A Humane Designer, Wien - New York 2003.

Fumihiko Maki. 'Group Form.' Werk 7 (1963), pp. 258-263.

MoMA Press release, June 3, 1961, available at https://www.moma.org/documents/moma_press-release 326237.pdf, retrieved 31. 7. 2017.

Bernard Rudofsky, Architecture Without Architects. A Short Introduction to Non-Pedigreed Architecture, New York 1964.

Bernard Rudofsky, 'Introduzione al Giappone (I).' Domus 319 (June 1956), pp. 45-49.

Bernard Rudofsky, The Kimono Mind: An Informal Guide to Japan and the Japanese. New York 1965.

Felicity Scott, 'Underneath Aesthetics and Utility. The Untransposable Fetish of Bernard Rudofsky', Assemblage 38 (1999), pp. 58-89.

Felicity Scott, Disorientation: Bernard Rudofsky in the Empire of Signs, Berlin 2016.

Bruno Taut, Houses and People of Japan, Tokyo 1937.

Makoto Ueda, Kimono Mind (review), Pacific Affairs, 41(2) (1968), p. 286. 

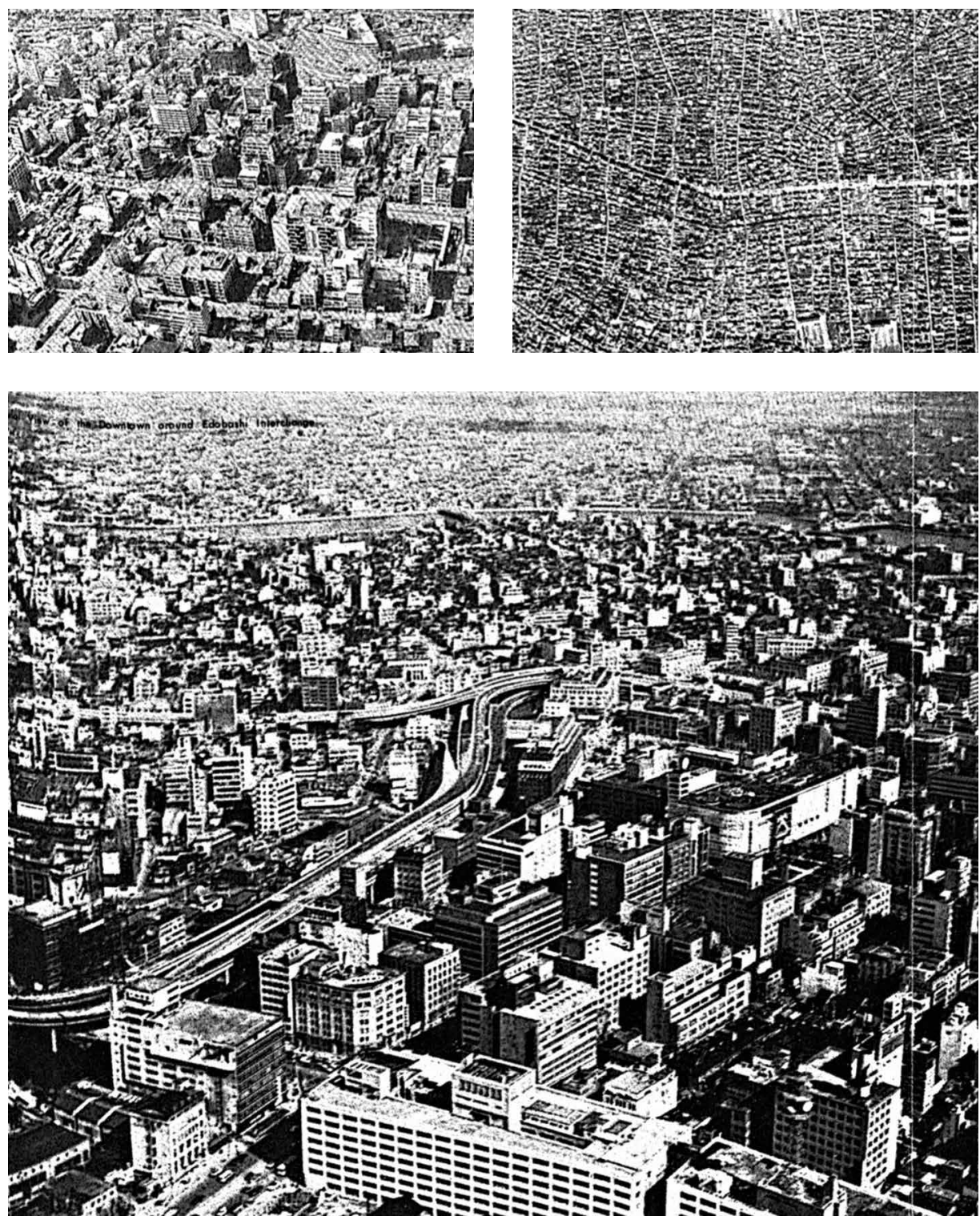

Figure 1. Tokyo urban planning was presented extensively on the occasion of the Olympics in 1964: Günther Nitschke, 'Olympic Planning and Dream Planning', Architectural Design, 101964.

Borrowed from Architectural Design, 10 1964, s. 483 


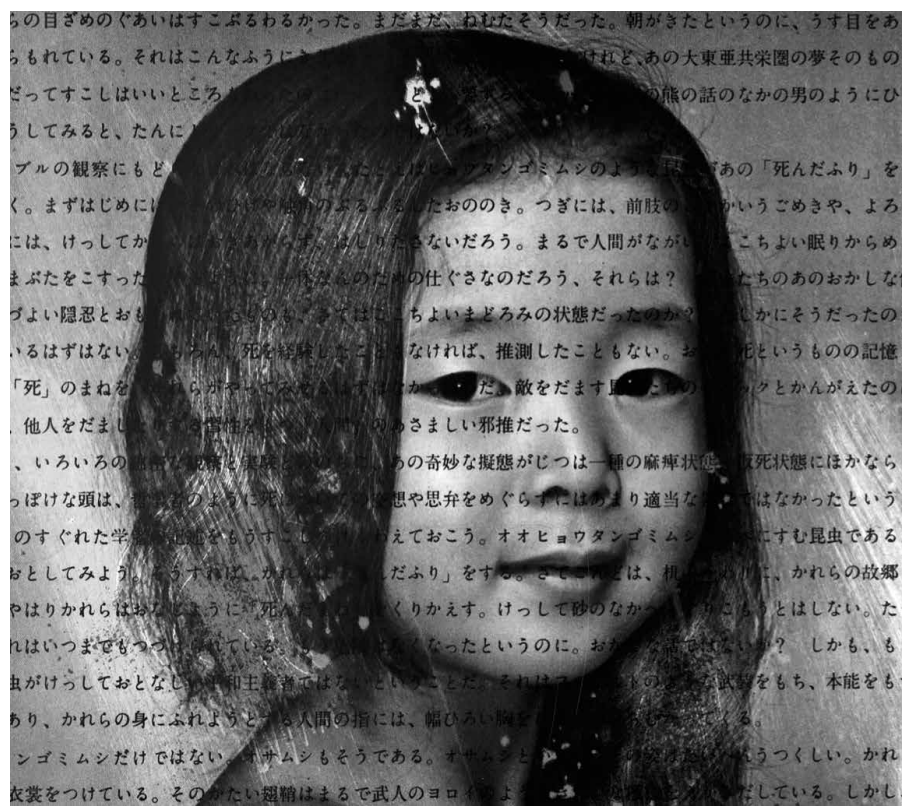

Figure 2. Bernard Rudofsky: Dust cover of The Kimono Mind, collage, 1965. (Guarneri, Bernard Rudofsky). Borrowed from Andrea Bocco Guarneri, Bernard Rudofsky. A Humane Designer, Berlin 2003, s. 168

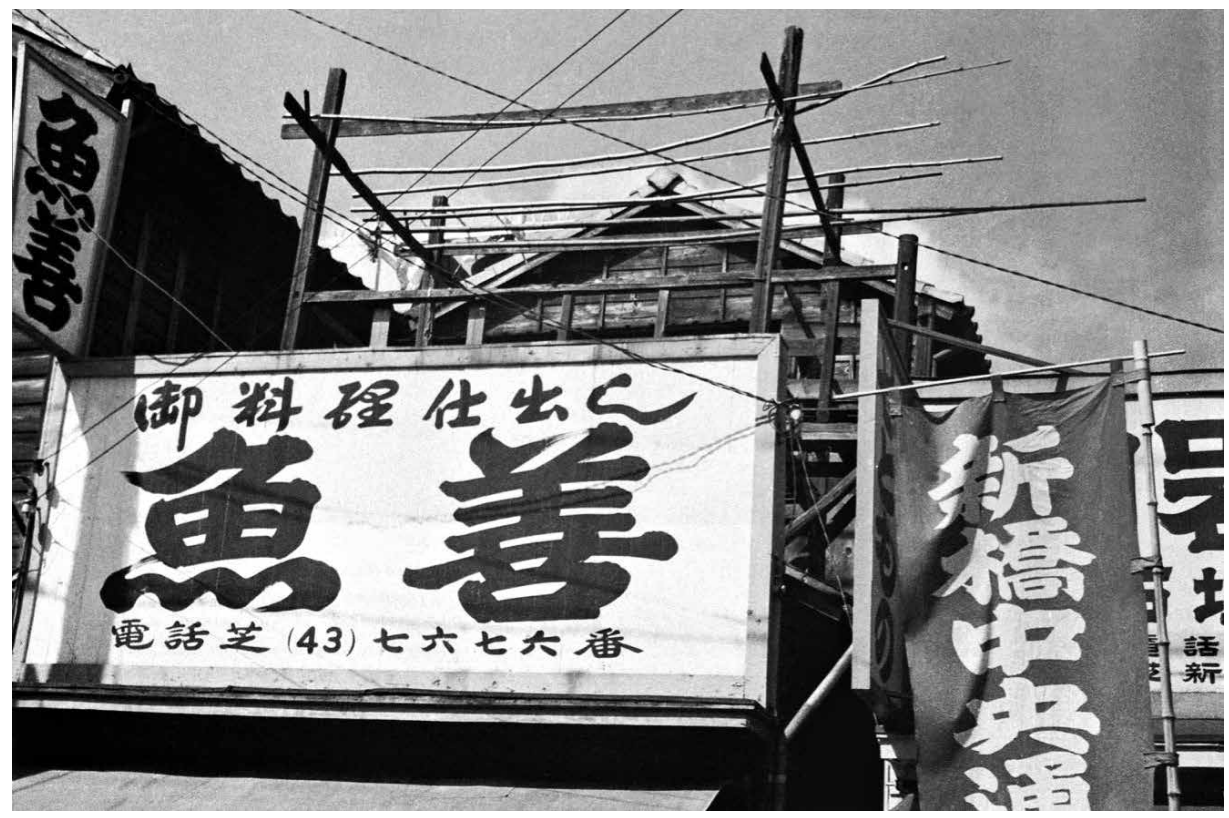

Figure 3. Bernard Rudofsky: Photograph from Japan, (Guarneri, Bernard Rudofsky). Borrowed from Andrea Bocco Guarneri, Bernard Rudofsky. A Humane Designer, Berlin 2003, s. 120 


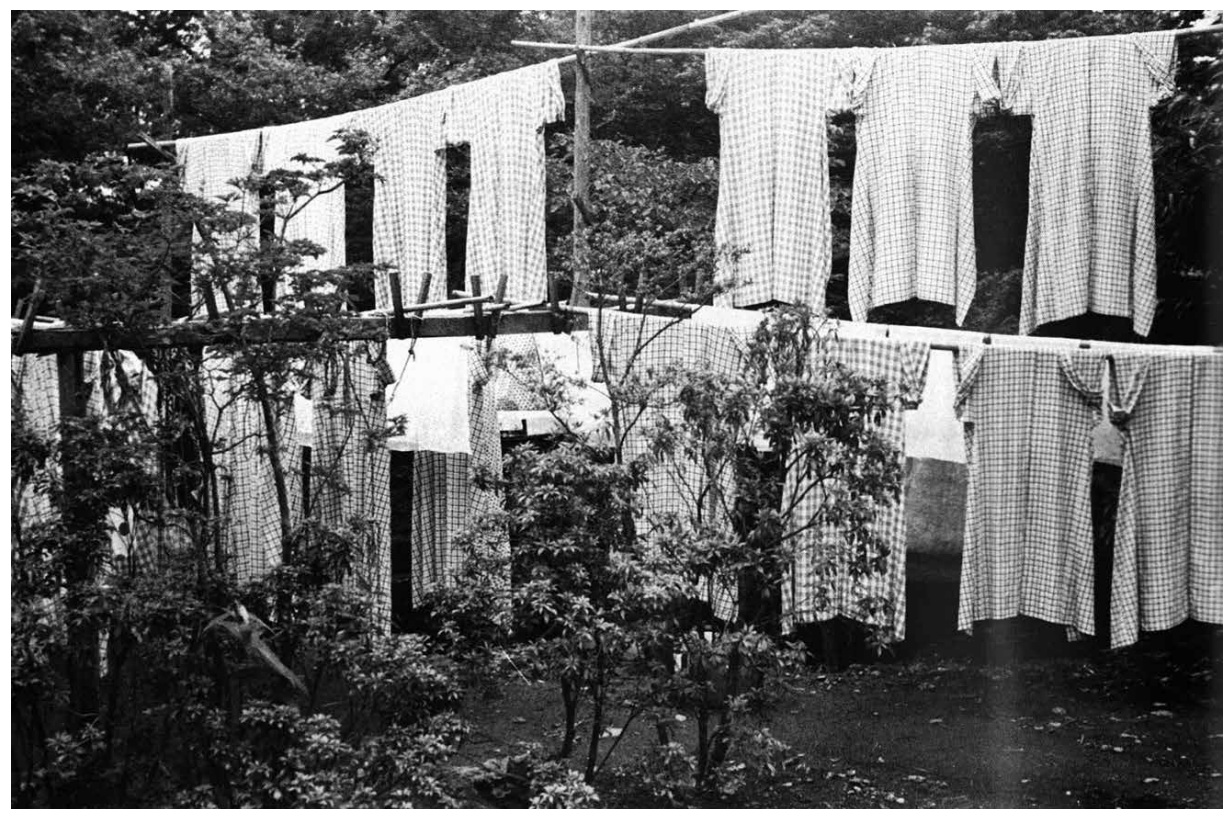

Figure 4. Bernard Rudofsky: Photograph from Japan. Clothing was one of Rudofsky's many interests. Borrowed from Andrea Bocco Guarneri, Bernard Rudofsky. A Humane Designer, Berlin 2003, s. 212

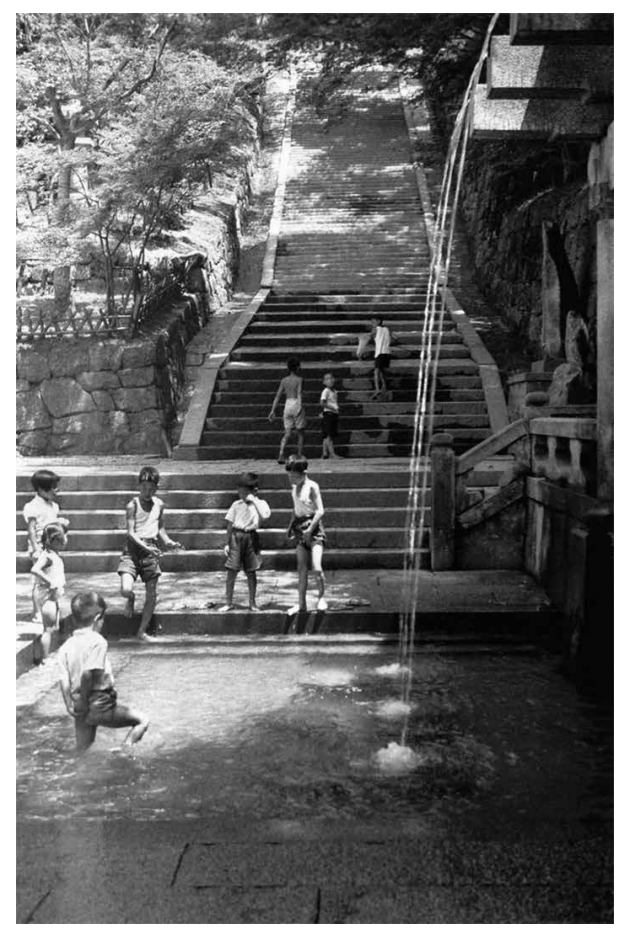

Figure 5. Bernard Rudofsky: Photograph from Japan. (Guarneri, Bernard Rudofsky). Borrowed from Andrea Bocco Guarneri, Bernard Rudofsky. A Humane Designer, Berlin 2003, s. 225 